\title{
Petani Cengkeh di Kelurahan Mannanti Sinjai, 1977-2018
}

\author{
Muh. Summung Awar, Amirullah, Ahmadin \\ Prodi Pendidikan Sejarah Fakultas Ilmu Sosial Universitas Negeri Makassar \\ muh.summung@gmail.com
}

\begin{abstract}
Abstrak
Penelitian ini bertujuan untuk mengetahui tentang Petani Cengkeh Di Kelurahan Mannanti (1977-2018) dengan memaparkan latar belakang petani cengkeh, perkembangan cengkeh, serta dampak pada kehidupan sosial ekonomi petani cengkeh di Kelurahan Mannanti tahun 1977 2018. Hasil penelitian menunjukkan bahwa latar belakang berkembangnya pertanian cengkeh di Kelurahan Mannanti adanya inisiatif sendiri yaitu s

eorang tokoh masyarakat bernama Gunawang Makkarateng selaku ketua APCI (Asosiasi Petani Cengkeh Indonesia) cabang Kabupaten Sinjai sekaligus petani pertama yang membudidayakan tanaman cengkeh. Adapun perkembangan petani cengkeh tidak terlepas dari tingkat pendapatan cengkeh baik sebelum, saat, dan sesudah diberlakukannya kebijakan pemerintah. Sementara dampak yang ditimbulkan yakni mampu mengubah kehidupan petani sebelum dan sesudah diberlakukan kebijakan pemerintah, yaitu munculnya kalangan haji baru, memiliki prabot rumah tangga seperti Televisi, Kulkas, DVD meja dan kursi tamu, meja makan dan sebagainya. Tidak ketinggalan pula kendaraan roda empat, dan sepeda motor, dan memiliki lahan pertanian yang luas serta menyekolahkan anaknya sampai di perguruan tinggi. Namun, pada saat diberlakukan kebijakan justru mengecewakan petani akibat harga cengkeh yang rendah. Munculnya juga kalangan elit baru dan kesempatan kerja bagi masyarakat lain dengan adanya sistem upah. Maka dapat di simpulkan bahwa petani cengkeh di Kelurahan Mannanti Kabupaten Sinjai (1977-2018) sebelum dan susudah diberlakukan kebijakan mengalami peningkatan. Namun pada saat diberlakukan kebijakan mengalami penurunan. Penelitian ini menggunakan metodologi penelitian sejarah yang meliputi heuristik yaitu tahapan pengumpulan data, kritik sumber bertujuan menilai dan menentukan sumber, interpretasi yaitu menafsirkan data dan tahap historiografi atau penyajian atau penulisan sejarah. Metode pengumpulan data dilakukan dengan cara penelitian lapangan terdiri dari wawancara dengan petani cengkeh dan mengumpulkan sumber arsip (arsip kantor kelurahan) serta literaturliteratur yang berhubungan dengan penelitian ini.
\end{abstract}

\section{Kata kunci: Petani Cengkeh, Mannanti}

\begin{abstract}
This study aims to find out about Clove Farmers in Mannanti Village (1977-2018) by describing the background of clove farmers, clove development, and the impact on the socio-economic life of clove farmers in Mannanti Village in 1977-2018. The results of the study showed that the background of the development of clove farming in the Mannanti village was that there was an initiative of its own namely a community leader named Gunawang Makkarateng as chairman of the Sinjai District branch of the Indonesian Clove Farmers Association and the first farmer to cultivate clove plants. The development of clove farmers is inseparable from the level of clove income both before, during, and after the implementation of government policy. While the impact that is caused is able to change the lives of farmers before and after the enactment of
\end{abstract}


government policies, namely the emergence of new hajj groups, having household furniture such as television, refrigerators, DVD tables and guest chairs, dining tables and so on. Do not miss the four-wheeled vehicles, and motorbikes, and have extensive agricultural land and send their children to college. However, when the policy came into effect, it disappointed farmers due to low clove prices. There is also the emergence of new elites and job opportunities for other communities with a wage system. So it can be concluded that the clove farmers in the Mannanti Kelurahan of Sinjai Regency (1977-2018), before and after the policy was enacted, had increased. However, at the time of its enactment the policy has decreased. This study uses a historical research methodology which includes heuristics, namely the stages of data collection, source criticism aimed at assessing and determining the source, interpretation of interpreting the data and historiographic stage or presenting or writing history. The method of data collection is carried out by means of field research consisting of interviews with clove farmers and collecting archival sources (village office archives) as well as literature relating to this research.

\section{Keywords: Clove Farmers, Mannanti}

\section{A. Pendahuluan}

Pertanian merupakan sektor utama dalam pembangunan dibidang ekonomi, hal ini disebabkan karena sebagian besar masyarakat indonesia masih menggantungkan kehidupannya pada sektor pertanian terutama dalam penanaman cengkeh. Cengkeh juga merupakan salah satu komoditi pertanian yang tinggi nilai ekonominya. Komoditi ini banyak digunakan di bidang industri sebagai bahan pembuatan rokok kretek, dan dibidang farmasi sebagai bahan pembuatan minyak atsiri. Mengenai asalusul tanaman cengkeh itu ada beberapa pendapat, antara lain cengkeh berasal dari Maluku Utara, Kepulauan Maluku, Philipina. (AAK, 1981).

Selain itu cengkeh juga merupakan tumbuhan yang kaya akan khasiat dan manfaat bagi kesehatan, dan perindustrian dan menyebabkan tanaman ini sebagai tanaman yang paling digemari oleh masyarakat, sehingga banyak masyarakat Indonesia yang bertempat tinggal didaratan tinggi membudidayakan tanaman cengkeh tersebut.

Cengkeh yang mempunyai kualitas bagus mempunyai nilai jual yang bagus pula. Tetapi, untuk mendapatkan kualitas cengkeh yang baik juga harus memahami cara budidaya cengkeh yang baik pula. Karena cengkeh merupakan tanaman musiman. Artinya, cengkeh tidak tersedia setiap saat bila tanpa diikuti dengan manajemen stok yang baik. (Soerkartawi, 2002). Usaha peningkatan jumlah dan mutu produksi tanaman cengkeh bagi para petani merupakan suatu keinginan yang besar karena cengkeh mempunyai banyak kegunaan dalam kehidupan manusia sehingga menyebabkan permintaan terhadap komoditi ini semakin bertambah, juga merupakan sumber mata pencaharian dan penghasilan para petani.

Sulawesi Selatan merupakan salah satu provinsi yang mempunyai potensi pertanian yang cukup besar dengan dukungan sumber daya alamiah yang cukup besar, serta memberikan peranan yang besar terhadap pendapatan regional Sulawesi Selatan. Perekonomian Sulawesi Selatan tidak hanya bersifat monokultur beras. Akan tetapi, telah diusahakan diversifikasi usaha pertanian terutama pengembangan usaha subsektor perkebunan, perikanan dan peternakan. Sejalan dengan hal itu, maka pengembangan subsektor pertanian sangat penting, salah satu diantaranya dengan jalan meningkatkan produksi tanaman perkebunan seperti cengkeh. 
Sejak tahun 1969/1970 pemerintah telah mencanangkan kebijaksanaan untuk ekstensifikasi dan intensifikasi tanaman cengkeh guna menunjang swasembada cengkeh di Indonesia. (Najiyati \& , 1991). Ini sejalan dengan Pelita I 1969/1970 dimana perluasan tanaman cengkeh telah di tingkatkan. Setiap tahun jutaan biji unggul tipe Zanzibar disebarluaskan oleh Direktorat Jenderal Perkebunan, Departemen Pertanian, hampir ke semua provinsi di Indonesia. (Hdiwijaya, 1986). Bisa jadi salah satu provinsi yang dimaksud adalah sulawesi selatan, dimana sesuai dengan wawancara penulis dengan salah satu petani yang ada di sinjai bahwa cengkeh itu berada di sulawesi selatan khusunya di sinjai itu tahun 1970-an.

Salah satu usaha yang diminati masyarakat di Kabupaten Sinjai khususnya Kelurahan Mannanti adalah budidaya tanaman cengkeh. Budidaya tanaman cengkeh mempunyai peran dalam aspek spesial ekonomi. Selain sebagai salah satu sumber pendapatan nasional juga sebagai sumber penghasilan petani cengkeh. Cengkeh yang ada di kelurahan mannanti merupakan jenis cengkeh Zanzibar yang di ambil dari Bogor pada tahun 1977.

Melihat kondisi perekonomian di Kelurahan Mannanti sejak tahun 19772018. Meskipun telah menghadapi berbagai kendala dalam mengstabilkan perekonomiannya. Namun, itu tidaklah menjadi penghambat petani cengkeh di Kelurahan Mannanti untuk tetap menggeluti pekerjaan sebagai petani cengkeh. Oleh karena itu, penulis tertarik untuk membahas lebih dalam lagi mengenai petani cengkeh di Kelurahan Mannati dan penulis berharap tulisan ini bisa memberikan kontribusi dan menambah khasanah pengetahuan terutama yang terkait dengan cengkeh yang ada di Kabupaten Sinjai.

\section{B. Metode Penelitian}

Setiap penelitian adalah deksripsi secara cermat dan didasarkan atas teori dan metode. Secara umum metode dianggap sebagai cara-cara strategis untuk memamhami realistas, langkah-langkah sistematis untuk memecahkan rangkaian sebab akibat berikutnya. Penelitian, dari kata dasar "teliti" didenifisikan sebagai kegiatan pengumpulan dan pengolahan data yang disajikan secara sistematis dan objektif.

\section{Heuristik}

Heuristik berasal dari bahasa Yunani "Heuristiken" yang berarti menemukan atau mengumpulkan sumber. Menemukan dan mengumpulkan data dalam kaitannya dengan ilmu sejarah ialah sumber sejarah yang berupa catatan, kesaksian, dan faktafakta lain yang dapat memberikan informasi atau gambaran tentang sebuah peristiwa yang menyangkut kehidupan manusia.. Adapun sumber-sumber sejarah dibedakan menjadi tiga kategori, yang pertama yaitu sumber kebendaaan atau material yang berupa sumber tertulis (dokumen dan arsip Kelurahan Mannanti, BPS (Badan Pusat Statistik), foto pada saat wawancara kepada informan yang terdiri dari Bapak Gunawang Makkarateng, Bapak Ridwan, Bapak Alamsyah, Bapak H. Nurdait. Wawancara dengan Bapak Lurah Mannanati yaitu: Drs. A. M. Ali Imran. Hz, M,Si. Serta wawancara dengan salah seorang buruh tani, yakni: Erni.), dan sumber benda, yang kedua adalah sumber non kebendaan atau inmaterial yang dapat berupa kepecayaan, dan yang ketiga adalah sumber lisan. Sumber lisan dapat berupa wawancara. Dalam proses pengumpulan data cara yang dapat dilakukan adalah teknik wawancara.

Dalam metode heuristik ada beberapa teknik yang dapat dilakukan yaitu.

\section{a. Penelitian Lapangan.}

Penelitian lapangan dilakukan dengan cara wawancara dan observasi. Metode wawancara dilakukan dengan cara melakukan wawancara kepada petani, 
buruh petani, dan pemerintah setempat. Metode observasi yang dilakukan dengan cara melakukan pengamatan langsung terhadap lokasi yang diteliti. Dalam penelitian ini observasi dilakukan di Kelurahan Mannanti yang ada di Kabupaten Sinjai.

\section{b. Penelitian Pustaka.}

Penelitian pustaka yang dilakukan terkait dengan sumber-sumber tertulis seperti naskah, buku, dan jurnal. Dalam penelitian ini penelusuran sumber buku dan karya ilmiah yang berkaitan dengan Petani Cengkeh dilakukan di Perpustakaan Jurusan Pendidikan Sejarah, Perpustakaan Umum Universitas Negeri Makassar, Perpustakaan Wilayah Kota Makassar, Perpustakaan Daerah Kabupaten Sinjai, dan BPS Kabupaten Sinjai. Kemudian studi kearsipan yang biasanya berupa lembaranlembaran seperti arsip kantor kelurahan.

\section{c. Dokumentasi}

Dokumentasi merupakan catatan peristiwa yang sudah berlalu. Dokumen bisa berbentuk tulisan atau gambar. Dokumentasi yang berbentuk gambar misalnya seperti foto, gambar hidup, sketsa, dan lain-lain. Dalam penelitian ini dokumentasi yang ada berupa gambar dan foto yang terkait dengan Petani Cengkeh.

\section{Kritik}

Setelah mengumpulkan data langkah selanjutnya yang dilakukan adalah kitik sumber. Kritik sumber terbagi menjadi dua yaitu kritik intern dan krtitik ekstern. Kritik ektern dilakukan untuk menilai kelayakan suatu sumber. Kritik ekstern dilakukan untuk mengetahui sejauh mana keabsahan atau autentisitas sumber.

Kritik sumber yang dilakukan dengan melakukan perbandingan antara dokumen, buku, dan arsip dengan hasil kajian relevan yang terkait dengan penelitian. Diperlukan pengetahuan yang bersifat umum dalam mengetahui sifat konteks zaman.

\section{Interpretasi}

Interpretasi adalaah proses pemaknaan fakta sejarah dalam interpretasi terdapat dua poin penting yaitu sintesis (menyatukan) dan analisis (menguraikan). Fakta-fakta sejarah dapat diuraikan dan disatukan sehingga mempunyai makna yang berkaitan dengan satu sama lainnya. Faktafakta sejarah harus di interpretasikan atau ditafsirkan agar suatu peristiwa dapat direkonstruksikan dengan baik. (Sejarah, 2013). Interpretasi merupakan tahapan selanjutnya setelah penulis melalui kritik sumber. Dimana sumber-sumber yang didapatkan perlu di tafsirkan oleh peneliti.

Dalam tahap interpretasi, imajinasi seorang peneliti dibutuhkan untuk menafsirkan seluruh kejadian berdasarkan data-data yang terkumpul. Interpretasi sering juga disebut sebagai biang subyektifitas (Kuntowijoyo, 1995) oleh karena itu dalam proses penafsiran peneliti harus benar-benar berhati-hati sehingga tidak terjebak kedalam subyektifitas yang kadang kala juga sangat mempengaruhi hasil penulisan.

\section{Historiografi}

Historiografi atau penyajian merupakan langkah terakhir dari sebuah rangkaian metode penelitian sejarah, tahap ini merupakan proses penyusunan fakta-fakta ilmiah dari berbagai sumber yang telah diseleksi sehingga menghasilkan suatu bentuk penulisan sejarah yang bersifat kronologi atau memperhatikan urutan waktu kejadian serta menggunakan bahasa yang mudah di pahami.

\section{Tinjauan Lokasi Penelitian}

Aspek geografis merupakan suatu urgensi yang penting dipahami untuk mengetahui peristiwa dalam suatu wilayah baik pada masa lalu maupun masa yang akan datang karena dengan memahami setiap wilayah akan memudahkan untuk mengetahui perubahan-perubahan yang telah terjadi pada daerah tersebut. Sebelum membahas jauh tentang Petani Cengkeh di Keluarahan Mannanti, penulis akan menuliskan dengan singkat tentang kondisi Geografis Kelurahan Mannanti. Mannanti adalah kelurahan yang berada di dalam wilayah administrasi Kabupaten Sinjai. 
Kabupaten Sinjai sendiri merupakan salah satu dari 23 kabupaten/kota dalam wilayah Provinsi Sulawesi Selatan yang berjarak 223 km dari Ibu kota Makassar (Ibu kota Provinsi Sulawesi Selatan). Kabupaten Sinjai terletak di pantai timur bagian selatan jazirah Sulawesi Selatan. (Yasir, 2018)

Secara devenitif Kabupaten Sinjai terdiri dari sembilan kecamatan dan 80 desa/kelurahan. Kabupaten Sinjai memiliki luas $81,996 \mathrm{~km}^{2}$ atau $1,801 \%$ dari luas wilayah Provinsi Sulawesi Selatan. Secara ekonomi, daerah ini memiliki letak strategis karena memiliki dua jalur perhubungan, yaitu darat dan laut. Jalur darat menghubungkan kota kabupaten atau kota provinsi yang menjadi pusat kegiatan ekonomi. Sedangkan, jalur laut digunakan untuk hubungan antar daerah diluar Provinsi Sulawesi Selatan.

Kelurahan Mannanti merupakan salah satu kelurahan yang terletak di Kecamatan Tellulimpoe dengan jarak tempuh $\pm 5 \mathrm{~km}$ dari Ibu kota Kecamatan Tellulimpoe yang memiliki ketinggian sekitar 500 mdpl. Adapun luas Kelurahan Mannanti menurut data statistik Kabupaten Sinjai Tahun 2018 adalah $9,72 \mathrm{~km}^{2}$ atau $927 \mathrm{Ha}$ dengan jarak tempuh ibu kota kabupaten Sinjai $36 \mathrm{~km}^{2}$.

Kelurahan Mannanti memiliki cukup banyak potensi penduduk. Adapun jumlah penduduk mencapai \pm 4.779 jiwa terdiri dari 2.421 jiwa laki-laki dan 2.358 jiwa perempuan. Adapun jumlah kepala keluarga adalah $\pm 1.335 \mathrm{kk}$. (Nur, 2018)

Berdasarkan hasil penelitian menunjukkan bahwa penduduk Keluarahan Mannanti memiliki mata pencaharian sebagai karyawan, peternak dan sebagai petani/pekebun. Dari 2537 orang sebagai petani/pekebun, \pm 1911 sebagai petani cengkeh, dan \pm 626 sebagai petani sawah, karet, dan lain-lain. (Yasir, 2018)

Adapun keadaan sosial budaya masyarakat Kelurahan Mannanti yaitu adanya sistem upah mengupah yang berlaku sampai sekarang dan bekerja sama dalam berbagai bidang, baik dalam hal fisik bangunan maupun pertanian.

Terkhususnya dalam pertanian cengkeh.

\section{Pembahasan}

\section{Latar Belakang Dimulainya Pertanian Cengkeh}

Petani merupakan jumlah yang mayoritas dalam kehidupan masyarakat di Indonesia hal tersebut, didukung oleh sumber daya alam, sumber daya manusia, dan sumber daya social (Soetomo, 2012) terutama yang terdapat di daerah pedesaan. Petani sebagai salah satu kelompok dalam kehidupan masyarakat telah menempatkan diri dan berpartisipasi dalam proses pembangunan. Dengan demikian, kehadiran petani disebabkan oleh berbagai faktor, baik faktor lingkungan, geografis maupun sumber daya alam (Rahman, 2017). Ketiga faktor tersebut memberikan kesempatan dan peluang kepada petani dalam mengembangkan berbagai jenis tanaman pertanian, utamanya tanaman cengkeh. Tanaman cengkeh (Syzigium aromaticum) termasuk tanaman jangka panjang dan merupakan tanaman tahunan.

Mengingat pentingnya cengkeh sebagai salah satu jenis tanaman unggulan yang memberikan rangsangan kepada para petani untuk membudidayakan tanaman tersebut. Di Sulawesi Selatan, utamanya di Kelurahan Mannanti Kabupaten Sinjai cengkeh sudah mulai dikembangkan oleh masyarakat petani. Hal ini disebabkan karena masih adanya ketersediaan lahan yang masih cukup luas dalam artian lahan kosong. Hal ini sesuai dengan perkataan salah seorang narasumber yang menyebutkan bahwa lahan yang dimiliki masih sangat luas sehingga masyarakat mengalihkan perhatian kepada jenis tanaman cengkeh meskipun tidak semua masyarakat melirik tanaman cengkeh pada saat itu. Oleh karena itu, mulai pada tahun 1977, masyarakat di Kelurahan Mannanti secara bertahap mulai membeli dan mengembangkan tanaman cengkeh. Hal inilah yang melatar belakangi petani untuk 
menanam cengkeh di Kelurahan Mannanti. (Makkarateng, 2018).

Selain itu, tanaman cengkeh memiliki nilai ekonomis yang cukup tinggi, dan dapat dipetik dalam waktu \pm 3-5 tahun tergantung dari jenis dan lingkungannya seperti masyarakat di Kelurahan Mannanti. Hal ini yang menjadi alasan masyarakat di Kelurahan Mannanti untuk menanam cengkeh yang di pelopori oleh Gunawang Makkarateng. Adapun jenis tanaman cengkeh yang di tanam oleh masyarakat di Kelurahan Mannanti yaitu tipe Zanzibar, Si Putih, Si Ambon, Si Kotok.

Perkembangan budidaya tanam cengkeh di Kelurahan Mannanti Kecamatan Tellulimpoe tentunya tidak terlepas dari peran pemerintahan dan masyarakat petani dalam rangka meningkatkan perkembangan pertanian di Kelurahan Mannanti. Perhatian pemerintah terhadap sektor perkebunan cengkeh di Kelurahan Mannanti pada dasarnya didukung oleh potensi sumber daya alam yang dimiliki. Selain itu, pembentukan kelompok tani merupakan rangkaian upaya meningkatkan pengetahuan petani serta adanya penyuluhan sekali satu bulan. Langkah yang ditempuh oleh pemerintah tersebut menunjukkan kesadaran masyarakat akan pentingnya pengembangan sumber daya manusia dalam pembangunan. Karena itu, untuk melibatkan masyarakat secara langsung tanpa didukung oleh pengetahua maka akan menimbulkan permaslahanpermasalahan dalam pelaksanaan pembangunn.

Upaya pembanguna sektor pertanian di Kelurahan Mannanti pada dasarnya dilakukan seiring dengan pogram pembangunan nasional yang menitikbertakan pada sektor pertanian. Dalam kaitannya pembangunan pertanian di Keluarahan Mannanti Kabupaten Sinjai, nampaknya sasaran tersebut menjadi landasan gerak pembangunan pertanian. Karena petani juga merupakan unsur dalam melaksanakan pembangunan secara rasional dan berencana, utamanya pembangunan pertanian di Kelurahan.

\section{Perkembangan Pertanian Cengkeh di Kelurahan Mannanti Kab. Sinjai}

Perkembangan adalah serangkaian perubahan progresif yang terjadi karena adanya proses yang terus berkembang dan tidak boleh menurun. Adapun petani adalah suatu profesi yang bergelut di bidang pertanian, utamanya dengan cara melakukan pengelolaan tanah dengan tujuan untuk menumbuhkan dan memelihara tanaman. Sedangkan, perkembangan petani adalah suatu proses yang ditunjukkan untuk selalu menambah produksi pertanian, mempertinggi pendapatan serta menambah modal dalam pertanian untuk meningkatkan kesejahteraan masyarakat.

Perkembangan petani cengkeh di Kelurahan Mannanti tidak lepas dari peningkatan kebutuhan dalam skala lokal maupun nasional. Di Kelurahan Mannanti tingkatan pengelolaan usaha petani cengkeh mengalami perubahan sejak tahun 19772018.

a. Fase Awal Penanaman dan Pengembangan (1977-1980)

Pada tahun 1977-1980 merupakan fase awal penanaman dan pengembangan tanaman cengkeh di Kelurahan Mannanti selama 3 tahun. Pada fase ini, jenis bibit yang di kembangkan oleh petani cengkeh adalah bibit jenis Zanzibar. Pada fase awal penanaman tanaman cengkeh tersebut tentunya dikatakan sebagai tahap percobaan, karena partisipasi petani dalam merespon penanaman tanaman cengkeh masih relatif kurang. Hal ini disebabkan oleh adanya pola pikir yang masih mengandalkan pola pertanian lama, yaitu sebagai petani sawah. Selain itu masih banyaknya lahan yang sebenarnya potensial untuk ditanami cengkeh.

b. Fase Produksi Pertama dan Periode Awal Perkembangan (1981-1992)

Pada tahun 1981-1992 merupakan fase perkembangan budidaya tanaman cengkeh 
di Kelurahan Mannanti Kabupaten Sinjai. Hal tersebut ditandai dengan peningkatan produksi dan jumlah petani, sekaligus tingkatan harga yang harus diterima oleh petani untuk hasil pertaniannya. Pada fase ini juga perlu diketahui proses pemasaran cengkeh. Pemasaran cengkeh itu sendiri merupakan salah satu kegiatan dalam perekonomian yang membantu dalam menciptakan nilai ekonomi. Nilai ekonomi itu sendiri menentukan harga dan jasa.

Berdasarkan pada konsep inti pemasaraan yang meliputi kebutuhan (needs), keinginan (wants), dan permintaan (demands). Manusia harus menentukan kebutuhannya terlebih dahulu sebelum ia memenuhinya. Usaha untuk memenuhi kebutuhan tersebut dapat dilakukan dengan cara mengadakan suatu hubungan. Dengan demikian pemasaran juga bisa diartikan suatu usaha untuk memuaskan kebutuhan pembeli dan penjual.

Pada praktiknya, keadaan pemasaran cengkeh di Keluarahan Mannanti sering dipengaruhi oleh pedagang yang langsung membeli cengkeh kepada petani. Ada beberapa situasi pemasaran yang terjadi. Pertama, pihak petani langsung menjual hasil perkebunan cengkehnya ke pedagang pengumpul, pedagang perantara, atau pedagang besar. Dalam hal ini, petani cengkeh di Kelurahan Mannanti memiliki posisi tawar yang lemah. Harga lebih banyak dipengaruhi oleh pembeli. Situasi kedua, pihak pembeli yang mencari produsen dalam hal ini petani. Pada situasi ini, petani cengkeh dapat memperoleh harga yang relatif lebih baik. Hal ini seringkali terjadi, terbukti dengan adanya pemesanan dengan uang muka terlebih dahulu oleh pembeli kepada petani sementara bunga cengkeh belum layak panen. Dengan adanya hubungan kerjasama antara petani dengan peadagang pengumpul yang disebut juga patroklien dan ini masih berlaku sampai sekarang. (Ridwan, 2019).

Berubahnya pola pikir masyarakat petani untuk mengembangkan dan membudidayakan tanaman cengkeh tersebut, sehingga petani mendapatkan tingkat harga yang sesuai dan tidak stabil. Hal ini dapat dilihat dari harga cengkeh di awal tahun 80-an yang mencapai kisaran harga Rp. 4.000- Rp. 7.300. Karena harga sangat mempengaruhi perkembangan petani, tentu perlu kestabilan penetapan harga untuk cengkeh. Sehingga mutu dan produksi cengkeh dapat pula mengalami peningkatan terus. Oleh karena itu, masih perlu juga adanya penyuluhan lapangan yang lebih intensif untuk meningkatkan kebutuhan petani dan dapat mendukung perkembangan petani cengkeh.

c. Fase Kebijakan Keputusan Presiden (Keppres) (1993-1997)

Pada tahun 1993-1997 merupakan fase kebijakan pemerintah. Dimana pemerintah mengeluarkan kebijakan terkait dengan cengkeh yakni pada tanggal 11 April 1992 dikeluarkan sebuah Keputusan Presiden Nomor 20 Tahun 1992 yang mengatur Tata Niaga Cengkeh termasuk didalamnya penetapan harga dan baru berlaku pada tahun 1993. Harga pada saat itu berkisaran Rp 2.500- Rp. 2.750 dan semua proses pemasarannya sama dengan fase awal perkembangan.

Dengan dikeluarkan keputusan pemerintah seperti yang telah dijelaskan, tentu berdampak pada kehidupan petani dan perkembangan pertanian cengkeh di Kelurahan Mannanti Kabupaten Sinjai. Mengingat hanya seperdua dari harga cengkeh sesungguhnya yang diterima oleh petani. Hal tersebut, menimbulkan kekecewaan bagi petani. Jumlah tersebut dianggap minim untuk memenuhi berbagai kebutuhan petani, baik kebutuhan akan pendidikan, kesehatan maupun yang lainnya. Oleh karena itu, tidak sedikit petani yang mengabaikan dan meninggalkan tanaman cengkeh.

d. Dinamika Produksi Pertanian Cengkeh (1998-2018)

Terjadinya krisis ekonomi menimbulkan gerakan reformasi yang menghendaki adanya perubahan 
kehidupan bermasyarakat, berbangsa, dan bernegara ke arah yang lebih baik secara kostitusional. Artinya, adanya perubahan kehidupan dalam bidang politik, ekonomi, hukum, sosial, dan budaya yang lebih baik, serta demokrasi berdasarkan prinsip kebebasan, persamaan, dan persaudaraan. Dengan adanya gerakan reformasi dari berbagai pihak mengakibatkan masa orde baru berakhir ditandai dengan mengundurkan diri presiden Soeharto pada tanggal 21 Mei 1998 dan menunjuk wakilnya B.J. Habibie sebagai presiden RI, maka lahir pula masa reformasi di Indonesia. Di Kelurahan Mannanti tingkatan pengolahan usaha petani cengkeh mengalami perubahan sejak tahun 1998. Saat itu terjadi krisis ekonomi di perkotaan, tetapi petani-petani di berbagai daerah khususnya di Kelurahan Mannanti malah meningkat dikarenakan harga cengkeh meningkat.

Memasuki tahun 1999 keadaan tersebut justru terbalik. Petani yang sebelumnya menelantarkan dan bahkan banyak diantara mereka yang menebang percuma tanaman cengkehnya, kembali memelihara dan mengurus dan bahkan tidak sedikti pula petani membuka jalan lahan baru untuk menanam cengkeh. hal ini disebabkan karena harga cengkeh kembali mengikuti harga pasar. Harga kembali normal, secara langsung pula mengubah kehidupan sosial ekonomi petani cengkeh.

Puncak ramainya petani beralih menjadi petani cengkeh yakni pada tahun 2001. Hal ini yang memicu petani segera beralih karena harga cengkeh kering pada saat itu mencapai Rp. 45.000 harga tersebut secara langsung mengubah kehidupan masyarakat petani dan tidak terkecuali masyarakat di Keluarahan Mannanti. Pesatnya kenaikan harga bunga cengkeh yang terjadi khususnya di Kelurahan Mannanti Kabupaten Sinjai menjadikan petani termotivasi dalam mengembangkan pertanian cengkeh yang lebih besar lagi sehingga dengan sendirinya menciptakan tenaga kerja yang lebih besar pula.
Perkembangan petani selanjutnya tahun 2002-2007 harga cengkeh kembali stabil dan berkisaran Rp. 26.667- Rp. 47.333 per $\mathrm{kg}$ dan bahkan ada yang kurang dari itu. Tahun 2004 dan tahun 2007 produksi yang dihasilkan sangat meningkat drastis sekitar \pm 20 ton. Kemudian, di tahun 2008-2018 harga cengkeh berkisaran Rp. 45.667- Rp. 135.333. Namun, harga pada saat itu tidak sebanding nilainya pada tahun-tahun sebelumnya karena nilai tukar rupiah dengan dollar yang semakin tinggi bandingannya, dan hasil panennya juga menurun disebabkan karena cuaca yang tidak menentu, sehingga pemeliharannya juga kurang, dan di tahun 2008 turun drastis \pm 5 ton sehingga penghasilan tinggal \pm 15 ton begitu pula tahun-tahun berikutnya terus menurun sampai di tahun 2018 produksi cengkeh yang dihasilkan \pm 6 ton dan harga juga turun menjadi Rp. 40.000. Meskipun demikian, produksi dan harga turun pendapatan tetap meningkat. Sama halnya dari kedua fase sebelumnya proses pemasaran tetap sama yaitu adanya pedagang pengumpul yang berdatangan untuk membelih cengkeh di petani sebaliknya petani mencari pedagang pengumpul dikarenakan harga yang begitu melonjat.

Karena harga sangat mempengaruhi perkembangan petani untuk meningkatkan perkembangan pertanian cengkeh. Hal tersebut tetap disyukuri para petani karena selain pemanfaatan bunga cengkeh yang tidak diketahui oleh petani, biaya produksi dan pemeliharaan telah dianggap setara dengan harga yang ditetapkan.

\section{Dampak Pertanian Cengkeh Pada Kehidupan Sosial Ekonomi di Kelurahan Mannanti Kab. Sinjai}

Adapun dampak perkembangan cengkeh di Kelurahan Mannanti yaitu sangat berdampak sekali karena perubahanperubahan yang terjadi di masyarakat sangat signifikan terutama dalam bidang ekonomi, sosial, dan pendidikan.

a. Dampak Dalam Bidang Ekonomi 
Sektor pertanian masih berperan penting dalam pembangunan ekonomi dan pengurangan kemiskinan di Indonesia. (Subandi, 2016) Keberlangsungan hidup manusia senantiasa dihadapkan pada proses kebutuhan hidupnya. Manusia memerlukan sandang-pangan dan papan untuk menunjang kesehariannya dalam beraktifitas di tengah-tengah masyarakat. Keterkaitan antara masyarakat dan kegiatan ekonomi dikaji dalam sosiologi ekonomi. (Damsar \& Indrayani, 2015)

Sosiologi ekenomi mengkaji masyarakat yang didalamnya terdapat pola interaksi sosial, dalam hubungannya dengan ekonomi. Hubungan dilihat dari sisi saling pengaruh mempengaruhi. Masyarakat sebagai realitas ekternal-obyektif akan menuntun individu dalam melakukan ekonomi seperti apa yang boleh diproduksi, bagaimana memproduksinya, dan dimana memproduksinya. Tuntutan tersebut berasal dari budaya, termaksud didalamnya hukum dan agama. (Damsar \& Indrayani, 2015)

Masyarakat yang bekerja sebagai petani merupakan bidang yang mewarnai kehidupan masyarakat di Keluarahan, sehingga tidak dapat diabaikan dalam perkembangan sejarah sosial yang memihak kehidupan masyarakatnya bahwa pertanian dan perkebunan merupakan tempat menanam tanaman yang menhasilkan untuk masyarakat. Sehingga tidak heran bila pertanian merupakan bagian dari kehidupan msayarakat di Kelurahan Mannanti dalam meningkatkan produktivitas perekonomian.

Berdasarkan penelitian yang dilakukan nampak bahwa keadaan ekonomi masyarakat petani cengkeh di kelurahan Mannanti dapat dilihat dari beberapa segi antara lain: tingkat pendapatan, kualitas rumah, kepemilikan barang rumah tangga, dan kepemilikan lahan pertanian. Dengan demikian dapat di simpulkan bahwa masyarakat petani cengkeh di kelurahan Mannanti mengalami peningkata di bidang ekonomi.

b. Dampak Dalam Bidang Sosial

Keluarga merupakan unit sosial yang paling mendasar dalam kehidupan petani. Perubahan-perubahan yang terjadi ditingkat keluarga dapat kita ketahui karena adanya faktor lingkungan dari masyarakat. Karena masyarakat dipandang sebagi sistem sosial, yaitu pola interaksi sosial yang terdiri atas komponen sosial yang teratur dan melembaga. Karakteristik sebuah sistem sosial, yaitu struktur sosial yang mencakup susunan status dan peran yang ada di satuan sosial yang memunculkan nilai-nilai dan norma yang akan mengatur interaksi antar status dan peran sosial tersebut. Pada struktur sosial terdapat unsur-unsur sosial yang pokok, misalnya kaidah-kaidah sosial, lembaga sosial, dan lapisan sosial. (Jamaluddin, 2015)

Masyarakat yang menjadi bagian dari struktur sosial akan melakukan tindakan sosial yang bertujuan untuk mencapai tujuan yang diinginkan. Cengkeh memberikan banyak sekali perubahanperubahan interaksi sosial yang terjadi di dalam masyarakat itu sendiri. Bukan hanya itu, kesejahteraan sosial yang dirasakan juga adalah munculnya kalangan elit baru (Haji) seperti Bapak H. Nurdait, Bapak H. A. Abd. Aziz, Bapak H. Ibrahim, Ibu Hj. Hasriani, Ibu Hj. Murni, Bapak H. Ali, Ibu Hj. Husna, Ibu Hj. Hasni, Ibu $\mathrm{Hj}$. Ros, Ibu $\mathrm{Hj}$. Nurjiah, Ibu Hj. Maryam, Ibu $\mathrm{Hj}$. Norma, dll. Selain itu, keadaan sosial masyarakat petani cengkeh di Kelurahan Mannanti dapat juga kita lihat dari segi kerja sama dan sistem bagi hasil. Sehingga dapat disimpulkan bahwa dalam bidang sosial petani cengkeh di kelurahan Mannanti sangat erat dalam bekerja sama 
baik dalam sistem pemetikan maupun dalam sistem bagi hasil.

c. Dampak Dalam Bidang Pendidikan

Perubahan sosial lain yang nampak dalam masyarakat petani cengkeh di Kelurahan Mannanti adalah pemenuhan kebutuhan pendidikan bagi anak-anak mereka. Seperti yang di kemukakan oleh seorang narasumber yang menyebutkan bahwa keinginan petani untuk menyekolahkan anak-anak mereka tidak lain adalah untuk memberikan ilmu pengetahuan dan bekal di masa depan. Di samping itu, petani mengingingkan agar anak-anak mereka menduduki jabatan yang penting dalam kehidupan bermasyarakat atau pun dapat mengembangkan pertanian cengkeh yang sudah ada sebelumnya.

Keikutsertaan petani dalam dunia pendidikan merupakan salah satu peran serta petani untuk mewujudkan suksesnya pendidikan nasional dan pencanangan wajib belajar. Pendidikan tidak hanya di dapat dalam lingkungan keluarga, akan tetapi juga melalui lembaga pendidikan formal seperti sekolah maupun jenis pendidikan lainnya. Oleh karena itu, besar kecilnya pendapatan akan sangat mempengaruhi tingkat kesejahteraan. Pendapatan seseorang akan mempengaruhi erhadap keberadaan dalam masyarakat, dimana posisi akan menentukan status sosial dalam masyarakat. Karena semakin tinggi tingkat pendapatan seseorang maka kebutuhan baik sandang, pangan, maupun papan akan dengan mudah dapat terpenuhi, namun sebaliknya semakin rendah pendapatan seseorang maka akan semakin sulit pula untuk memenuhi semua kebutuhan hidupnya. Akan tetapi, sejak mula di budidayakan tanaman cengkeh di Keluarahan Mannanti para petani secara tidak langsung mendapatkan hasil yang baik serta penghasilan yang cukup dalam penanaman cengkeh. Cengkeh bisa dikatakan sebagai kunci keberhasilan di Kelurahan Mannanti dalam meningkatakan taraf perekonomian masyarakat yang bekerja sebagai petani.

Penghasilan dari bertani cengkeh dapat dikatakan mampu memenuhi kebutuhan sehar-hari petani cengkeh. Meskipun hasil yang diproduksi berkurang begitu pula harga yang tidak stabil namun petani cengkeh masih bisa mencukupi kebutuhan sehari-hari. Bahkan uangnya masih cukup sampai pemetikan/panen cengkeh tahun berikutnya.

\section{E. Kesimpulan}

Latar belakang masyarakat petani cengkeh di kelurahan Mannanti untuk menanam cengkeh karena cuaca dan iklimnya sama persis yang ada di bogor. Selain itu, adanya ketersediaan lahan yang masih kosong sehingga petani di Kelurahan Mannanti menanam cengkeh yang dipelopori oleh Bapak Gunawang Makkarateng sekaligus Ketua APCI cabang Kab. Sinjai dan mengikuti langkah-langkah pembudidayaan tanam cengkeh dengan baik. Dan tidak terlepas dari peran pemerintah, yaitu adanya penyuluhanpenyuluhan yang dilakukan oleh Cabang Dinas Perkebunan sekali satu bulan terhadap kelompok-kelompok tani di Kelurahan Mannanti untuk meningkatkan sektor pertaniannya. Adapun perkembangan petani cengkeh tidak terlepas dari tingkat pendapatan cengkeh baik sebelum, saat, dan sesudah diberlakukannya kebijakan pemerintah. Sementara dampak yang ditimbulkan yakni mampu mengubah kehidupan petani sebelum dan sesudah diberlakukan kebijakan pemerintah. Namun, pada saat diberlakukan kebijakan justru mengecewakan petani akibat harga cengkeh yang rendah. Munculnya juga kalangan elit baru dan kesempatan kerja bagi masyarakat lain dengan adanya sistem upah. Maka dapat disimpulkan bahwa petani cengkeh di Kelurahan Mannanti Kabupaten Sinjai 
(1977-2018) sebelum dan susudah diberlakukan kebijakan mengalami peningkatan. Namun pada saat diberlakukan kebijakan mengalami penurunan.

\section{DAFTAR PUSTAKA}

AAK, 1981. Petunjuk Bercocok Tanam Cengkeh. Yogyakarta: Kanisus.

Hdiwijaya, T., 1986. Cengkeh: Data dan Petunjuk ke Arah Swasembada. Jakarta: Gunung Agung.

Jamaluddin, A. N., 2015. Sosiologi Perdesaan. Bandung: Penerbit Pustaka Setia Bandung.

Kuntowijoyo, 1995. Pengantar Ilmu Sejarah. Yogyakarta: Benteng.

Makkarateng, G., 2018. Wawancara [Wawancara] (26 Oktober 2018).

Najiyati, S. \& D., 1991. Budidaya dan Penangan Pasca Panen Cengkeh. Jakarta: Penebar Swadaya.

Nur, M. Y., 2018. Buku Monografi Kelurahan Mannanti. Mannanti: Kantor Kelurahan.

Rahman, A. 2017 Pemanfaatan Lahan Pekarangan oleh Rumah Tangga Petani di Desa Bulutellue.

Ridwan, 2019. Wawancara [Wawancara] (15 Juni 2019).

Sejarah, T. P. J. P., 2013. Pengantar Ilmu Sejarah. Makassar: Balai Penerbit UNM.

Soerkartawi, 2002. Prinsip Dasar Manajemen Pemasaran Hasil-Hasil Pertanian: Teori dan Implikasinya. Jakarta: Raja Grafindo Persada.

Soetomo, 2012. Keswadayaan Masyarakat Manifestasi Kapasitas Masyarakat untuk Berkembang Secara Mandiri. Yogyakarta: Pustaka Pelajar.

Subandi, 2016. Ekonomi Pembangunan. Bandung: Alfabeta. 